\title{
The Grammar of Conflict: A Case Study on the Experiential Construal of Conflict in a Parallel Fictional Corpus
}

\author{
Daniel Antonio de Sousa Alves \\ Federal University of Paraíba (UFPB), João Pessoa, Brazil
}

\begin{abstract}
This paper presents a corpus-based case study on the linguistic construal of armed conflicts on the parallel corpus Grande Sertão: Veredas and The Devil to Pay in the Backlands. Drawing on Halliday's (1998) and on Pagano and Figueredo's (2011) explorations of how human experiences are transformed into meaning through language, this study is designed to analyze the lexicogrammatical resources employed to construe the experience of conflict in Portuguese and in English. The results point to the experience of conflict being construed as a Participant in Material Clauses, characterized by being a permanent entity in the temporal axis and by being able to actualize Processes and to take part in different Processes. Moreover, the results indicate the Conflict is construed as a self-governing entity — configured as if it could start, develop, and end itself, independently from human beings involved.
\end{abstract}

Keywords: Translation Studies, Systemic-Functional Linguistics, Corpus Linguistics, translation and conflict, parallel corpus Grande Sertão: Veredas and The Devil to Pay in the Backlands

\section{Introduction}

This paper presents a corpus-based case study on the linguistic construal of the armed conflicts fought between disputing groups (henceforth Conflict) presented in the novels Grande Sertão: Veredas (written in Brazilian Portuguese by Guimarães Rosa) and The Devil to Pay in the Backlands (translation of Grande Sertão: Veredas into English, carried out by James L. Taylor and Harriet de Onís). The study draws on the Hallidayan principle of exploring the ways complex human experiences are transformed into meaning through language, in order to understand what constitutes our assumed reality; it also draws on Pagano and Figueredo's (2011) method for comparing lexicogrammatical resources in parallel corpora.

This analysis focuses on the lexicogrammatical resources employed, in Portuguese and in English, for construing Conflict on a fictional parallel corpus. By exploring language in order to understand Conflict, this investigation acknowledges the power of language in construing "our experience of the social world"-as Butt, Lukin, and Matthiessen $(2004$, p. 270) put it -and considers language as the first means through which conflicts are shaped, enemies are defined, and social processes (such as defenses or attacks, for instance) are organized.

The following questions serve as a guideline for this investigation: (1) How is the experience of Conflict ideationally configured in the corpus? (2) What does this configuration reveal about the armed conflicts fought

Daniel Antonio de Sousa Alves, doctor in Translation Studies, professor at the Translation Program, Department of Intercultural Mediation, Federal University of Paraíba. 
in the corpus, in terms of transitory versus permanent states? and (3) What do the linguistic patterns reveal about these human experiences?

For answering the questions above, this paper is organized as follows: The second section (below) presents the Systemic Functional Grammar and its understanding of the figures of change that constitute our assumed reality. The third section presents the corpus, the different spheres of conflicts it depicts and the methods of analysis adopted in this study. At last, the fifth and sixth sections present, respectively, the results and the final remarks.

\section{Theoretical Background}

The Systemic Functional Grammar has been developed since the 1950s-1960s as a linguistic theory focused on the description of language in context. Considering language as a social semiotic system that both construes and enacts human experience, the theory has a semantic basis and relies on linguistic choices (made by human beings) to describe how meanings are construed.

From a systemic functional perspective, language realizes three Metafunctions simultaneously: (1) the Ideational Metafunction - related to how experiences are construed and how speakers make sense of their assumed realities; (2) the Interpersonal Metafunction - related to the resources and aspects that influence interactions between human beings; and (3) the Textual Metafunction-related to the internal organization of texts. This study, as previously mentioned, investigates the linguistic construal of Conflict, focusing on the Experiential Component of the Ideational Metafunction, which, according to Halliday and Matthiessen (2004), refers to how clauses are configured as quanta of change (as opposed to the Logical component of the Metafunction, which refers to how clauses are ranked, in terms of taxis).

As Halliday and Matthiessen $(2004,2014)$ point it out, reality is made out of a continuous flow of events (or goings on). The human perception of reality, nevertheless, is not based on the entire of that flow, but on chunks - or figures - that can be taken as quanta of change. From an ideational perspective, each quantum of change constitutes a clause, consisting of "a Process unfolding through time and of Participants being directly involved in this process in some way; and, in addition, there may be Circumstances of time, space, cause, manner or one of a few other types" (Halliday \& Matthiessen, 2014, p. 213). These clauses, or figures, can be visually represented as follows:

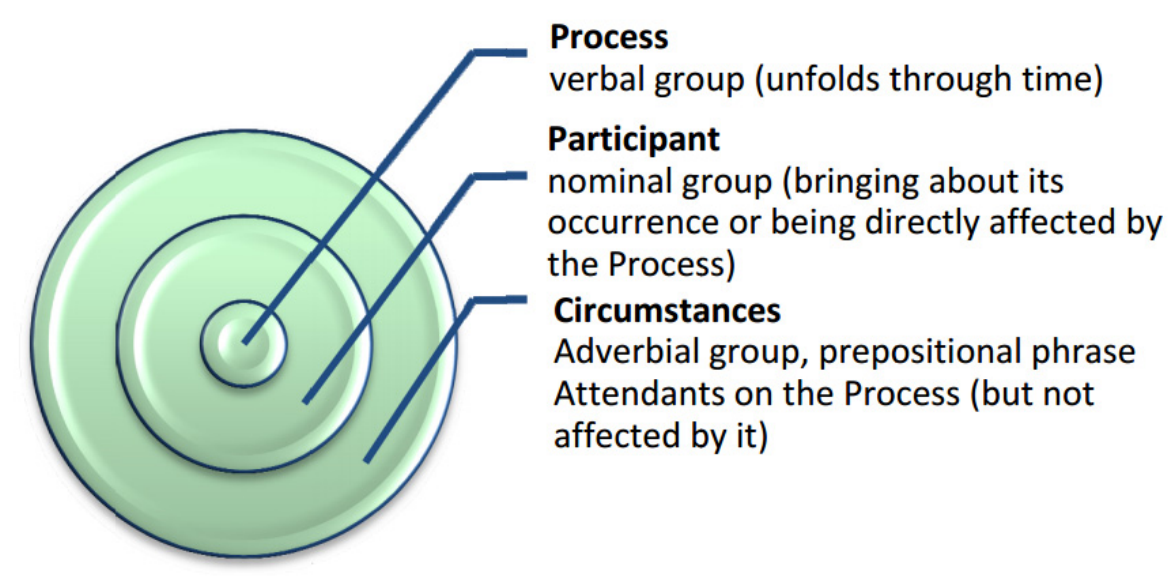

Figure 1. Elements in the structure of the clause, based on Halliday and Matthiessen (2014, p. 222). 
As Figure 1 above shows, the Processes are central elements to Clauses (from an ideational perspective), the Participants are elements close to the core, bringing about their occurrence or being directly affected by the Process, and the Circumstances are peripheral elements, which augment the Process (construing temporal, spatial and causal—among others — circumstances), but are not directly involved in it.

Due to its characteristic of unfolding through time, the Process can be said to be the element of the Clause that construes the notion of transitoriness in languages, whereas the Participant, by contraposition, construes notions of permanence. Both Halliday (1998) and Pagano and Figueredo (2011) argue for the contraposition "persistence versus transitoriness", referring to Participant as "(...) the entity that persists through time and takes part in various Processes" (Halliday, 1998, p. 316) and to the Process, as an element that conserves a transitory notion, for representing events and goings on in languages (Pagano \& Figueredo, 2011, p. 273).

Halliday and Matthiessen (2004) represent the spectrum of reality by means of six types of Processes: Material, Mental, Relational, Behavioral, Verbal, and Existential. These types account for the entireness of the experience, construing different aspects of our perceived reality, being brought about by (and affecting) different Participants. The following table summarizes the types of Processes, the aspects of the reality they construe and the Participants who actualize them and the Participants to which the Process can be extended.

Table 1

Aspects of Reality, Processes, and Participants

\begin{tabular}{|l|l|l|l|}
\hline Aspect of reality & Type of Process & $\begin{array}{l}\text { Participant who brings the } \\
\text { Process about }\end{array}$ & $\begin{array}{l}\text { Participants to which the Process } \\
\text { can be extended }\end{array}$ \\
\hline $\begin{array}{l}\text { Events and actions that prototypically take } \\
\text { place in the outer reality (of the Participants) }\end{array}$ & Material & Actor & Goal \\
\cline { 3 - 4 } & Scope \\
\hline $\begin{array}{l}\text { Recipient } \\
\text { perception }\end{array}$ & Client \\
\hline $\begin{array}{l}\text { Relations (of being and having) between } \\
\text { different entities }\end{array}$ & Relational & Carrier & Attribute \\
\hline $\begin{array}{l}\text { Physical and physiological behaviors } \\
\text { (typically human) }\end{array}$ & Behavioral & Behaven & Adtribute \\
\hline Speech representation and dialogic passages & Verbal & Sayer & Identified \\
\hline Existence and happening & & Behavior \\
\hline
\end{tabular}

The table above summarizes the different Processes and their respective Participants. Events and actions that take place in the outer reality (of the Participants), for instance, are construed by means of Material Processes, being actualized by Actors and are (or can be) extended to a number of different Participants (such as Goal, Scope, and Recipient, for instance).

The following section reviews the works by Halliday (1998), Pagano and Figueredo (2011), and Butt, Lukin, and Matthiessen (2004). Similar to the purpose of this paper, the formers investigate the experiential construal of Pain as a human experience using the Systemic Functional Grammar as theoretical background while the latter analyzes the ways two speeches related to post $9 / 11$ conflicts shape meanings, social processes, and material actions. 


\section{Investigating the Human Experience Through Language}

Halliday (1998) and Pagano and Figueredo (2011) analyze the construal of the experience of Pain as an aspect of our assumed reality. While Halliday deals with texts in English, Pagano and Figueredo tackle Brazilian Portuguese and Argentinean Spanish. Although the nature of the experience the authors investigate is fundamentally different from the experience of Conflict, the two articles are important for this paper for showcasing how language construes complex human experiences, constituting, as Halliday (1998) says, a "theory of human experience" (p. 307).

Drawing from the Systemic Functional Grammar, Halliday (1998) investigates the linguistic construal of the human experience of Pain, considering it a complex experience, which involves emotional, sensational, and physical aspects of reality. By investigating the occurrences of "pain", "hurt", "ache" and "sore" on the COBULID corpus, the author says pain can be assigned, in language, to parts of the human body (as in: "a sore stomach"), to qualities assigned to people (as in: "he's sore there, he's just a bit more tender") or impersonalized (as in: "show me where it's sore").

Following the Hallidayan investigation, Pagano and Figueredo (2011) analyze how the experience of Pain is construed in Brazilian Portuguese and Argentinean Spanish. The authors investigate a corpus of contemporary texts comprising the genres: (1) interviews; (2) informative texts; and (3) forums, and compare the lexicogrammatical resources available to Brazilian and Argentinean speakers to construe experiences of physical pain. The investigation of the occurrences of "dor", "dolor", "doer", and "doler" reveals that, both in Portuguese and Spanish, the experience of Pain tends to be construed as a Participant in Material, Relational, and Mental clauses - which implies the idea of pain as an experience that unfolds mostly in the outer reality of the human being, but that can also be related to other experiences and sensed in the inner reality of the human beings.

Also developing from the Systemic Functional Grammar, Butt, Lukin, and Matthiessen (2004) analyze two key speeches related to post 9/11 conflicts: one delivered by the former United States President George W. Bush in September 21, 2001, and the other delivered by Lieutenant Colonel Tim Collins on the eve of the invasion of Iraq (in March 2003). According to the authors, the speech delivered by Bush is construed to create the conditions necessary to an upcoming war, construing the "enemy" as the Actor in Material Clauses-thus, characterizing the enemy by its actions (and not its attributes, thoughts, or feelings). Moreover, in the speech delivered by Bush, the enemy actualizes a series of negative Processes (such as "To Kill”, "To Repress", "To Threaten", "To Overthrow", and "To Brutalize"), which are counterpoised by the positive Processes actualized by the Participants that represent the United States.

The closing statement on the speech - in which the former president announces that the United States will "meet violence with patient justice"-is emblematic of such a position or, in Butt, Lukin, and Matthiessen (2004) words, of how grammar "provides both concrete and abstract ways of construing violence" (p. 273). As Butt, Lukin, and Matthiessen (2004) emphasize, this closing statement (meeting violence with justice) can be read - in the context of an upcoming war-as "killing would be responded to with more killing" (p. 273). Nevertheless, in trying to discursively legitimize a Bellic endeavor, the former president highlights the negative characteristic of actions of the enemy and backgrounds the negative outcomes of the war on terror he, then, proposed - creating, thus, the opposition what "they" have done is "violence", and what "we" will do is "patient justice". 
The speech delivered by Lieutenant Colonel Tim Collins, on the other hand, reserves the role of Actor to Collins himself and his troops, construing the enemy as either Beneficiary or Circumstance. Differently from Bush, whose speech aimed at creating the conditions for a war, Collins aimed at creating a mindset in which his troops were in control over the Material and Mental experiences related to the war-which could explain why Collins and his troops are the Actors and Sensers in the Processes.

The following section aims at presenting a working definition of Conflict—not exhausting the discussion, but presenting factors to be considered for this analysis.

\section{Conceptualizing the Notion of Conflict}

Conflicts, as Birnbaum (1995) points out, are a fundamental part of the daily lives of all sorts of human groups (from couples to larger political parties). Although it is an important process for societies-for it defines social spaces and identities, and plays an important role in resolving divergences - it is a feared experience, whose definition is rather complex. For defining the notion of conflict, different authors and different theoretical perspectives can be taken into consideration, including (or not) notions of power, of social interests, of ideologies, etc. - as one can see in works by Baker (2006), Bachrach and Baratz (1962, 1970), Birnbaum (1995), Cohrs (2012), Lickel (2012), and Wallensteen (2012) — to name a few.

Among the plethora of factors involved in the notion of conflict, two points are to be highlighted for this study: (1) the acknowledgement of the Conflict as a daily experience and (2) the fictional societies involved in the Conflicts investigated, including their power structures, ideologies, and histories.

Acknowledging the conflict as a daily phenomenon justifies the affiliation of this study to the Systemic-Functional Linguistics, for it is a theoretical framework which facilitates understanding "how we as a species make sense of our daily experience by construing it in language" (Halliday, 1998, p. 307). By acknowledging Conflict as a daily experience and by analyzing the lexical and grammatical resources that construe Conflict in the corpus, this study aims at understanding how language can be used to transform the experiences of Conflict into meaning.

On what concerns the fictional societies involved in the conflicts, the internal organization of each group, their ideologies and the history of how they interact with one another are key elements to understand the armed conflicts portrayed in the novels. According to Wegner (2000), the fictional social groups presented in Grande Sertão: Veredas and The Devil to Pay in the Backlands are strongly dependent on their leaders and live under a continuous state of fighting (with few brief periods of peace). These characteristics lead those fictional groups to reject attempts to solve their conflicts by diplomatic negotiation or by means of due legal processes; also, it leads them to believe that the only means to achieve a state of peace is by the destruction of the rival group.

The actions taken by these social groups to achieve the destruction of their rivals and the reliance on violent means - such as attacking rival groups, instead of trying to find diplomatic solutions first-are indicatives of their ideological values as a society. The values they deem worth fighting for, the limits where the members of those groups are willing to let their leadership lead them to, and how they see themselves and the others.

The following section focuses on the parallel corpus Grande Sertão: Veredas and The Devil to Pay in the Backlands, and on the method for the analysis of the linguistic construal of the human experience of conflict. 


\section{Corpus and Method}

Grande Sertão: Veredas and The Devil to Pay in the Backlands constitute the parallel corpus to be analyzed in this paper. Published in 1956 in Brazilian Portuguese, written by João Guimarães Rosa, Grande Sertão: Veredas presents the ontological narrative of the former bandit Riobaldo. Addressing an unknown listener, Riobaldo reveals his life story — his life as a boy, his education, his family, his decision in joining a group of jagunços (outlaws), his love for Diadorim and his spiritual affliction concerning his doubts on the possibility of having closed a deal with the devil. Translated into English by Harriet de Onís and James L.Taylor, The Devil to Pay in the Backlands was published in 1963 and constitutes - to this day-the only translation of the novel into English.

A number of reasons justify the selection of this corpus for investigation. The first one refers to the importance of Grande Sertão: Veredas to the Brazilian literary canon and the importance of The Devil to Pay in the Backlands to the international visibility of the story. Not only is the translation into English the first one (of more than 18 translations into 11 languages) to be published, but it is also the only translation of a Brazilian novel on the list of the top 100 books of all time, published by the The Guardian newspaper in 2002, as pointed out by Alves (2011).

A second reason behind the selection of the novels refers to the importance of the notion of conflict to the story. According to Mulinacci ${ }^{1}$ (October 2011), the narrative of the novel is developed around different spheres of conflicts: From the linguistic choices the original text makes to the wars narrated by Riobaldo. The narrator, Riobaldo, himself can be seen as an emblematic conflicted character: He belongs to an outlaw group, but he has family ties with upper classes, he lives among an illiterate group, but he is an educated man, he loves his fellow jagunço (Diadorim), but does not accept the feeling and, thus, lives an internal conflict.

The third and main reason for analyzing this corpus, however, refers to the fictional wars depicted in the narratives. Set in the Brazilian backlands, the wars constitute examples of armed conflicts fought between disputing groups. The first war depicted in the novels is fought between the gang of followers of the characters Joca Ramiro against Zé Bebelo and the soldiers from the government, over territorial domain in the region. The second war is fought between the remainder of the gang of followers of Joca Ramiro against the gang of Hermógenes, over the assassination of Joca Ramiro (by Hermógenes). As previously stated, these instances of Conflict (the wars taken as experiences of armed conflict between disputing groups) are the focus of this analysis.

These Conflicts are to be considered, for the purposes of this analysis, as resulting from the "incompatible goals, competing interests, or fundamentally different values" of the human groups involved - as Baker (2006, pp. 1-2) puts it in her definition of conflict. The human groups involved can be characterized-as Wegner (2000) puts in his analysis of Grande Sertão: Veredas - by a non-diplomatic ideology, according to which, the only means for construing a state of peace is the destruction of the rival group.

The following section focuses on the method used in this investigation and on the decisions taken to carry out the analysis.

\section{Data Collection}

This investigation builds on the method systematized by Pagano and Figueredo (2011, pp. 296) to

\footnotetext{
${ }^{1}$ Presentation "Uma reflexão sobre a tradução de poesia, prosa e ensaio" (reflecting upon the translation of poetry, prose and essays), delivered by Roberto Mulinacci, at Federal University of Paraíba (Brazil), in October 3, 2011.
} 
investigate domains of human experience, based on parallel corpora. The research method suggested by the authors is based on principles of Corpus Linguistics and is affiliated to Systemic-Functional Linguistics, being applicable to this investigation.

The first step, according to them, is the selection of a domain of a human experience for investigation. For this study, the Conflict was defined as domain. The following steps refer to the selection of lexical items for investigation and to the gathering of concordance lines. For this study, the selection of items for investigation was based on the semantic notion of Conflict (comprising types semantically related to the armed Conflicts fought between disputing groups). The items were selected using the Wordlist tool, and their respective concordance lines were gathered by means of the Concordance tool of AntConc 3.4.3w software.

Having gathered the concordance lines, the following step for the investigation refers to the identification of the Experiential Categories (Processes, Participants, and Circumstances) of the lexical items explored as nodes of concordance lines. Another step is the identification of emerging linguistic patterns and the subsequent cross language comparison - presented on the next section of this paper.

\section{Results}

Initial analysis, using Wordlist, revealed the lexical items presented in the following table as representative of Conflict in Grande Sertão: Veredas and its translation into English:

\section{Table 2}

Lexical Items Representative of Conflict in the Corpus

\begin{tabular}{|l|l|}
\hline \multirow{3}{*}{ In Portuguese } & $\begin{array}{l}\text { 'Batalha', 'Batalhão, 'Batalhas', 'Briga', 'Brigando', 'Brigar', 'Brigaram', 'Brigas', 'Brigou', 'Briguei', } \\
\text { 'Combate', 'Combatemos', 'Combatendo', 'Combater', 'Combates', 'Combatia', 'Duelava', 'Duelo', } \\
\text { 'Contraguerra', 'Guerra', 'Guerraria', 'Guerras', 'Guerreando', 'Guerreantes', 'Guerrear', 'Guerrearam', } \\
\text { 'Guerreava,, 'Guerreei', 'Guerreia', 'Guerreio', 'Guerreiramente', 'Guerreiro', 'Guerreiros', and 'Mão-de-guerra' }\end{array}$ \\
\hline In English & $\begin{array}{l}\text { 'Battalion', 'Battle', 'Battles', 'Battling', 'Conflict', 'Conflicting', 'Confront', 'Confronted', 'Duel', 'Fight', } \\
\text { 'Fighter', 'Fighters', 'Fighting', 'Fights', 'Fought', 'War', 'Warfare', 'Warring', 'Warrior', 'Warriors', and } \\
\text { 'Wars' }\end{array}$ \\
\hline
\end{tabular}

The lexical items presented above were later explored as nodes in concordance lines, as shown in the following figures:

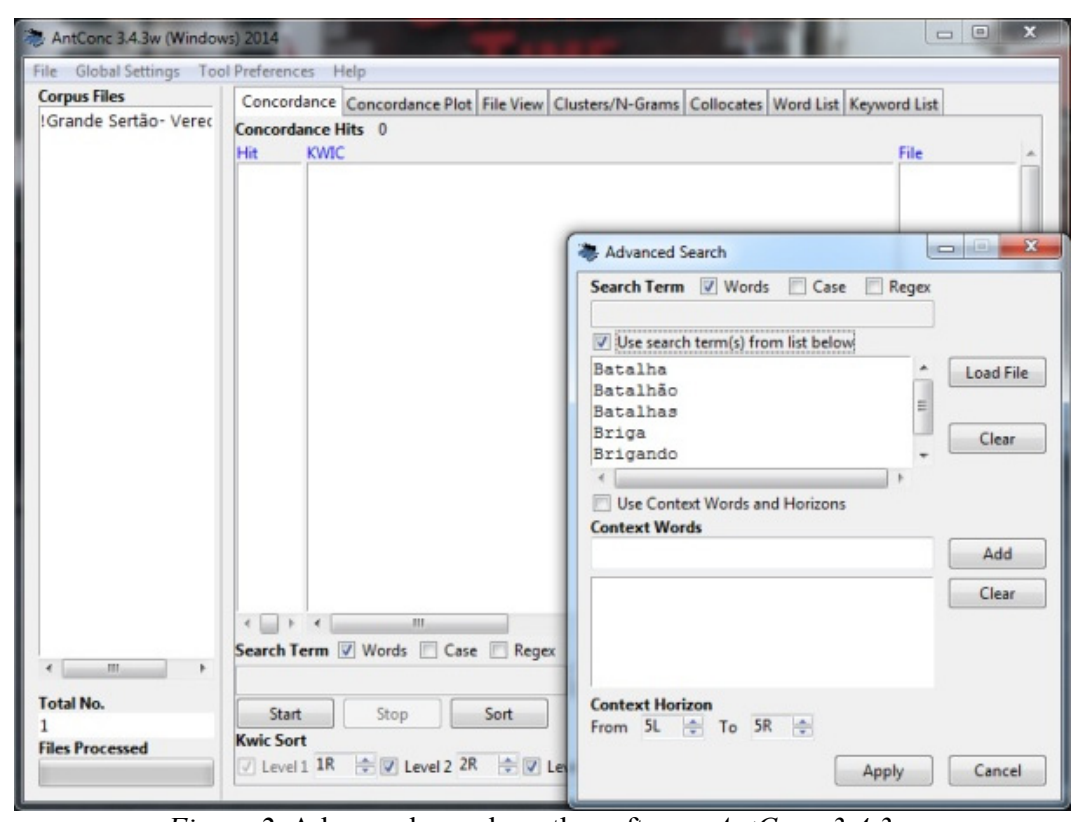

Figure 2. Advanced search on the software AntConc 3.4.3w. 


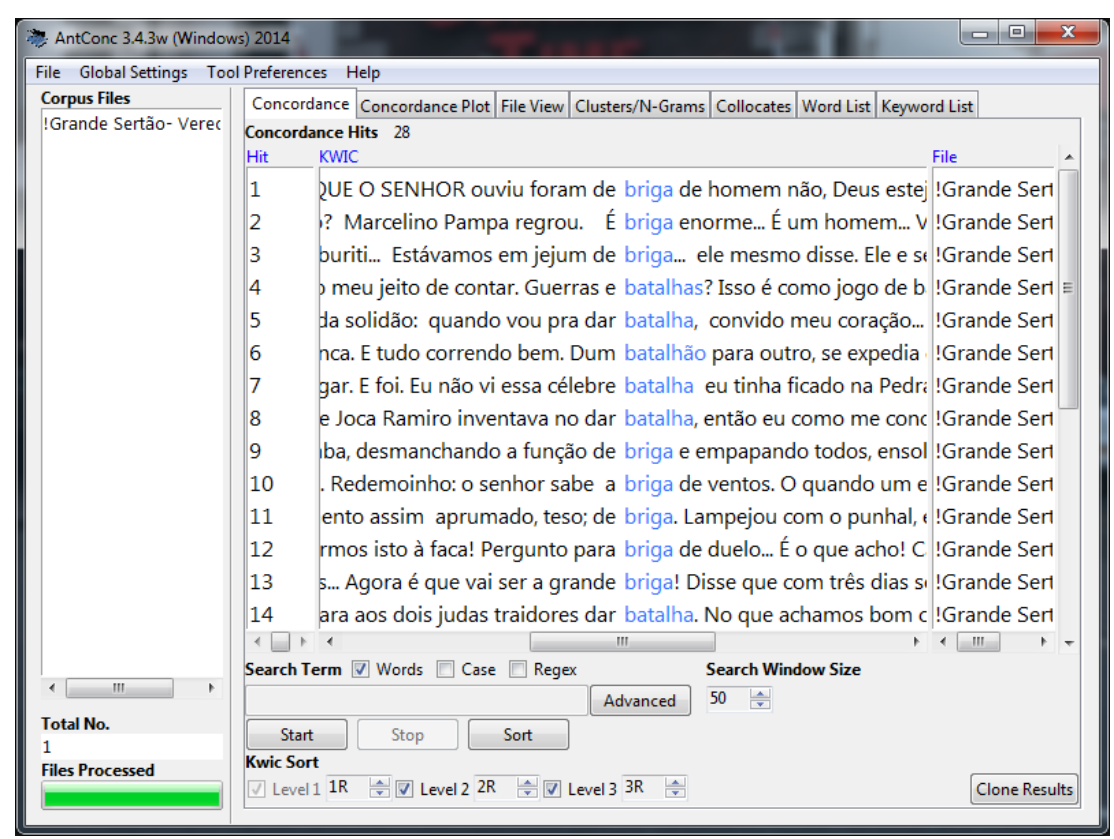

Figure 3. Concordance lines resulting from the advanced search.

Figures 2 and 3 (above) show, respectively, the advanced search tool of the software and concordance lines resulting from the process of investigation. These concordance lines were classified and annotated, in order to identify the Experiential Categories (Processes, Participants, and Circumstances) actualized by the key lexical items. The results from this step of the investigation are summarized in the following figure.

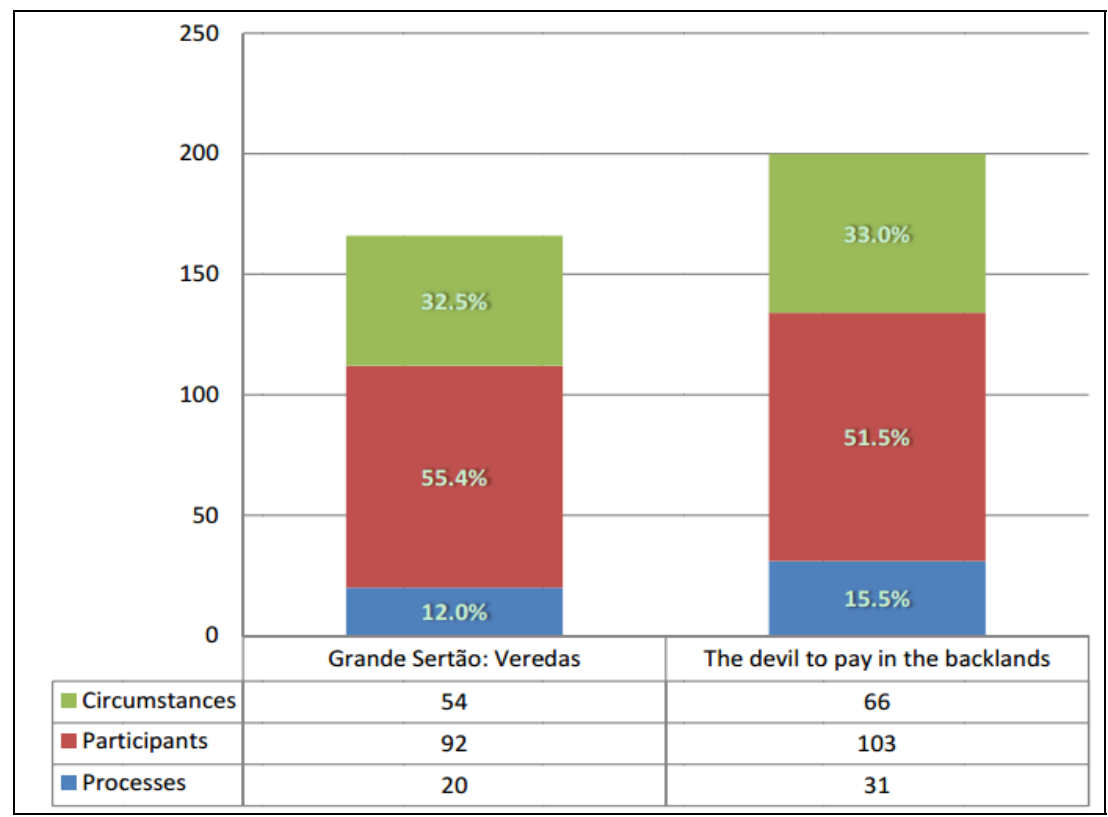

Figure 4. Experiential construal of Conflict in the corpus.

As Figure 4 shows, out of the 166 concordance lines in Portuguese, 92 (55.4\%) experientially construe the conflict by means of Participants; 54 (32.5\%) lines, by means of Processes; and 20 (12.0\%), by means of Circumstances. Out of the 200 concordance lines in English, 103 experientially construe (51.5\%), the conflict 
by means of Participants; 66 (33.0\%), by means of Processes; and 31 (15.5\%), by means of Circumstances.

These results bring out the characteristic of permanence of the experience of Conflict in the corpus. This characteristic can be highlighted both by the predominance of Participants and by the low percentage of Processes in the figures above. The characteristic of permanence can be seen as a break of expectations concerning the experiential construal of Conflict in the corpus: considering that conflicts are necessarily solvable and, thus, transitory (Wallesteen, 2012), one could expect a more transitory configuration in its experiential construal (implying a predominance of Processes).

The figures related to the conflict as Participant (92 Participants in Portuguese and 103 in English) can be broken down as follows:

Table 3

Participants Construing the Conflict in the Corpus

\begin{tabular}{|c|c|c|c|c|c|}
\hline & Participants & & tão: Veredas & & in the Backlands \\
\hline \multirow{6}{*}{ Material Clauses } & Actor & 16 & $17.4 \%$ & 23 & $22.3 \%$ \\
\hline & Goal & 16 & $17.4 \%$ & 21 & $20.4 \%$ \\
\hline & Scope & 0 & $0.0 \%$ & 1 & $1.0 \%$ \\
\hline & Recipient & 0 & $0.0 \%$ & 0 & $0.0 \%$ \\
\hline & Client & 0 & $0.0 \%$ & 0 & $0.0 \%$ \\
\hline & Attribute & 0 & $0.0 \%$ & 0 & $0.0 \%$ \\
\hline \multirow{2}{*}{ Mental Clauses } & Senser & 2 & $2.2 \%$ & 0 & $0.0 \%$ \\
\hline & Phenomenon & 15 & $16.3 \%$ & 9 & $8.7 \%$ \\
\hline \multirow{4}{*}{ Relational Clauses } & Carrier & 10 & $10.9 \%$ & 22 & $21.4 \%$ \\
\hline & Attribute & 2 & $2.2 \%$ & 3 & $2.9 \%$ \\
\hline & Identifier & 9 & $9.8 \%$ & 3 & $2.9 \%$ \\
\hline & Identified & 10 & $10.9 \%$ & 9 & $8.7 \%$ \\
\hline \multirow{2}{*}{ Behavioral Clauses } & Behaver & 0 & $0.0 \%$ & 0 & $0.0 \%$ \\
\hline & Behavior & 7 & $7.6 \%$ & 4 & $3.9 \%$ \\
\hline \multirow{4}{*}{ Verbal Clauses } & Sayer & 0 & $0.0 \%$ & 0 & $0.0 \%$ \\
\hline & Receiver & 0 & $0.0 \%$ & 0 & $0.0 \%$ \\
\hline & Verbiage & 3 & $3.3 \%$ & 1 & $1.0 \%$ \\
\hline & Target & 0 & $0.0 \%$ & 0 & $0.0 \%$ \\
\hline \multirow[t]{2}{*}{ Existential Clauses } & Existent & 2 & $2.2 \%$ & 7 & $6.8 \%$ \\
\hline & Total & 92 & $100.0 \%$ & 103 & $100.0 \%$ \\
\hline
\end{tabular}

As Table 3, above, shows, both in Portuguese and in English Conflict is most frequently construed as a Participant in Material Clauses - being an Actor in 17.4\% of the cases in Portuguese and in $22.3 \%$ of the cases in English; and a Goal in 17.4\% of the cases in Portuguese and 20.4\% of the cases in English. Considering that armed conflicts fought between disputing groups are, distinguishedly, Processes that unfold in the outer reality of the human beings (thus, fundamentally Material), this high frequency of Participants in Material Clauses can be said to be an expected result.

Focusing on the Material Clauses, a characteristic that strikes the attention of the analyst is the frequency Conflict is a Participant who actualizes Processes that denote a capability of self-control. The following excerpts are examples of such characteristic (emphasis added):

Example (1) They were to advance first — as decoys — and upset the enemy's calculations, when the fight started.

Example (2) Leagues away, fighting was going on. 
Example (3) [...], and soon the fighting stopped altogether. A good thing, too, for it was time to eat.

Examples (1), (2), and (3) show Conflict, as a Participant, who actualizes Processes that indicate some level of self-control - being able to start, develop, and end itself, as if these developments were not subjected to human actions. In the examples, the Actors "the fight", "fighting", and "the fighting" respectively actualize the Processes "started", "was going on", and "stopped". Conflict seems, thus, to be construed as a self-governing entity whose actions are not subjected to the human beings involved on the Processes of confrontation. Construing Conflicts in such a configuration can be seen as a means to shift liabilities over the conflict from the human beings to the conflicts themselves.

Conflict presents this characteristic of self-control both in Portuguese and in English. Out of the 16 Material Clauses in Portuguese in which the conflict is an Actor, 12 (75\%) actualize a Process of such characteristics (such as "tinha principiado" [HAD BEGUN], "findou" [ENDED], etc.). In English, this percentage amounts to $86.9 \%$ ( 20 out of 23 cases) - in which the conflict actualizes Processes such as "was going on", "started", "stopped altogether", "came", etc.

Considering the Material Clauses in which Conflict is a Goal (in Systemic-Functional Linguistics terms), in English, there are seven cases in which Conflict is controlled by a human entity. The following excerpts exemplify this situation:

Example (4) It was thus we began our many hard marches and indecisive battles and sufferings, whose melancholy tale I have told you, if I am not mistaken, up to the point of Zé [...]

Example (5) So now we had to begin the war all over again. Men and weapons.

Examples (4) and (5) show cases of Conflict realized as a Goal in Material Clauses (actualized by the human Actor represented by the pronoun "we" in both cases). In Portuguese, on the other hand, no cases in which the conflict is controlled by a human entity have been identified - another indication that, in Grande Sertão: Veredas, Conflict is construed as an independent, self-governing entity.

Still referring to the Material Clauses in which Conflict is a Goal in a Material Clause, another remarkable characteristic is the construal of this entity as something tangible, something that can be acquired, possessed, given, or touched, rather than something struggled over. The excerpts below exemplify these two cases (emphasis added):

Example (6) There was no warning. I gave battle.

Example (7) [...] came to the North, I did, bringing with me war and destruction, [...]

Example (8) My friend Medeiro Vaz once fought a battle at Conta-Boi, about two leagues from here.

Example (9) Our Chief, Medeiro Vaz, never lost a fight.

In the cases shown in Examples (6) and (7), Conflict, as Goal in Material Clauses, can be assigned to some degree of tangibility: In Example (6), the "battle" is something that can be given and in Example (7), "war and destruction" are construed as things that can be brought by someone. Examples (8) and (9), on the other hand, construe the conflict ("a battle" and "a fight", respectively) as something that can be fought or lost.

In the corpus Grande Sertão: Veredas and The Devil to Pay in the Backlands, when Conflict is a Goal in a Material Clause, it is more often construed as something tangible - meaning: a Goal in Processes of bringing, 
carrying, touching, etc., than something struggled over-meaning: a Goal in Processes of fighting, winning or losing. Out of the 16 cases in Portuguese, in which Conflict is a Goal, in 10, it is construed as something tangible and in three, as something to be struggled over. In English, out of the 21 cases in which Conflict is a Goal, in four cases it is construed as something tangible, and in six as something to be struggled over.

When Conflict is construed as a Process, it is - as one could expect-a Material Process. The examples below present some cases of Conflict as a Material Process (emphasis added):

Example (10) (...); he could fight a knife duel with the cunning of a cornered wildcat, on the aggressive every moment; (...)

Example (11) (...)-they fought like good citizens! Afterwards, the bandits returned with redoubled fury (...)

Example (12) We would fight as many as came, but a chief must make decisions.

Examples (10), (11), and (12) show Processes of fighting ("could fight", "fought", and "would fight", respectively) actualized by the Actors "he", "they", and "we" in the outer realities or their Participants. In all the 51 cases (20 in Portuguese and 31 in English) in which Conflict is construed as a Process, it is a Material Process. The result can be said to be expected, due to the nature of the human experience herein selected for analysis - considering, for that statement, that armed conflicts fought between disputing groups are expected to be actualized in the outer reality of their Participants.

At last, when Conflict is construed as a Circumstance, it augments the Processes it attends to in a wide range of possibilities. The most frequent Circumstances are those of Location (Time), Manner (Means), Cause (Purpose), and Projection (Matter). The examples below show some of these cases:

Example (13) After the battle at Tamanduá-tão I had sent him off, to pry and spy, to range far and wide, like a dog $[\ldots]$

Example (14) I'll tell about our battles, the fame that is our due. "Not mine, no, sir", I said.

Examples (13) and (14) present cases in which Conflict is construed as Circumstances of time and of subject, respectively. Whereas in Example (13), the prepositional phrase "after the battle" localizes the Clause (I had sent him off) in time; in Example (14), "our battles" construes, as a Circumstance, the subject about which the Participant tells.

\section{Conclusion}

Drawing on Halliday's (1998) and on Pagano and Figueredo's (2011) investigations of language, this paper aimed at presenting a corpus-based case study on the linguistic construal of the armed conflicts fought between the disputing groups presented in the parallel corpus Grande Sertão: Veredas and The Devil to Pay in the Backlands.

In trying to understand how the human experience of Conflict is construed in Portuguese and in English, the corpus was analyzed and types, semantically related to the notion of Conflict, were selected for investigation. Using the software AntConc 3.4.3w, concordance lines were gathered and the nodes were analyzed in terms of experiential configuration.

The analysis revealed that Conflict is most frequently a Participant in the Clauses investigated - both in Portuguese (55.4\% of the cases) and in English (51.5\% of the cases). The result implies it (Conflict) is non-transitory in the corpus - constituting an entity that persists through time, actualizes Processes, and/or 
takes part in different Processes. Focusing on the Material Clauses in which Conflict is an Actor, a remarkable pattern is the construal of Conflict as an entity that actualizes Processes that denote a capability of self-control. The configuration, as pointed out, not only implies Conflict as a self-governing entity, but also shifts the liability of the Processes of confrontation from the human beings involved, to the Conflicts (as entities) themselves - a more marked characteristic in the Portuguese text than in English text.

This characteristic of self-control is, perhaps, the linguistic pattern that called the attention of the analyst the most. It is possible to read it as an indication of a euphemistic approach towards construing the experience of Conflict in the languages investigated - considering euphemism as the use of "vague words as a means of making something seem more positive than it might otherwise appear", as both Jones and Peccei (2004, p. 48) and Simpson and Mayr (2010, p. 45) define it. By changing the liability over the processes of confrontation from the human groups to the Conflicts themselves, Conflict is turned into a less brutal experience for the human beings involved-for this configuration allows speakers to constitute an assumed reality in which Conflict is not something they fight themselves, but as an entity that starts, develops, and ends itself.

\section{References}

Alves, D. (2011). Correlações de forças e representatividade dos diferentes países em listas de melhores livros: uma análise polissistêmica das listas divulgadas pelos periódicos Folha de São Paulo (1999) e The Guardian (2002) (Correlation of forces and representativeness of countries in lists of best books: Analyzing the lists by the newspapers Folha de São Paulo and The Guardian from a polysystemic perspective). Dossiê In-Traduções, 5, 122-142. Retrieved September 25, 2012 from http://goo.gl/COtgw

Anthony, L. (2012). AntConc3.4.3w. Tokyo, Japan: Waseda University. Retrieved January 4, 2012 from http://goo.gl/3GVS

Bachrach, P., \& Baratz, M. S. (1962). The two faces of power. American Political Science Review, 56(4), 947-952. Retrieved April 9, 2014 from http://goo.gl/7wZ4Xw

Bachrach, P., \& Baratz, M. S. (1970). Power and poverty: Theory and practice. New York: Oxford University Press.

Baker, M. (2006). Translation and conflict: A narrative account. New York: Routledge.

Birnbaum, P. (1995). Conflitos (Conflicts). In R. Boudon (Org.), Tratado de Sociologia (Treaty of sociology). Rio de Janeiro: Jorge Zahar. Retrieved January 20, 2012 from http://goo.gl/tGZm9

Butt, D., Lukin, A., \& Matthiessen, C. (2004). Grammar-The first covert operation of war. Discourse \& Society, 15(2-3), 267-290.

Cohrs, J. C. (2012). Ideological bases of violent conflict. In L. Tropp (Ed.), The Oxford handbook of intergroup conflict. New York, NY: Oxford University Press.

Guimarães Rosa, J. (1963). The devil to pay in the backlands. (L. T. James \& H. Onís, Trans.). New York: Knopf.

Guimarães Rosa, J. (1994). Grande Sertão: Veredas (The devil to pay in the backlands). Rio de Janeiro: Nova Aguilar (ed.).

Halliday, M. (1998). On the grammar of pain. In J. J. Webster (Ed.), The collected works of M.A.K. Halliday (Studies in English language) (Vol. 7, pp. 306-336). London: Continuum.

Halliday, M., \& Matthiessen, C. (2004). An introduction to functional grammar. London: Oxford University Press.

Halliday, M., \& Matthiessen, C. (2014). Halliday's introduction to functional grammar. London \& New York: Routledge.

Jones, J., \& Peccei, J. S. (2004). Language and politics. In L. Thomas, S. Wareing, I. Singh, J. Stilwell Peccei, J. Thornborrow, and J. Jones (Eds.), Language, society and power: An introduction. London: Routledge.

Lickel, B. (2012). Retribution and revenge. In L. Tropp (Ed.), The Oxford handbook of intergroup conflict. New York, NY: Oxford University Press.

Pagano, A., \& Figueredo, G. (2011). Gramaticalização da dor em português e espanhol: uma abordagem comparada com subsídios da linguística de corpus e da linguística sistêmico-funcional (Grammaticalization of "pain" in Portuguese and in Spanish: A corpus-based comparative approach built upon systemic-functional linguistics). In V. Viana and S. E. O. Tagnin (Eds.), Corpora no ensino de línguas estrangeiras (Corpora and foreign language teaching). São Paulo: HUB Editorial.

Simpson, P., \& Mayr, A. (2010). Language and power: A resource book for students. New York: Routledge. 
Wallensteen, P. (2012). Understanding conflict resolution: War, peace and the global system. Los Angeles, London, New Delhi, Singapore, Washington DC: SAGE.

Wegner, R. (2000). Sertões desvendados (The backlands (sertões) unveiled). Dados, 43(3), 601-626. Retrieved May 9, 2014 from http://goo.gl/XGR53Q 